\title{
Recent Geoethical Issues in Moroccan and Peruvian Paleontology
}

\author{
JUAN CARLOS GUTIÉRREZ-MARCO \\ Institu to de Geociencias (CSIC, UCM), Madrid, Spain \\ jcgrapto@ucm.es
}

ARTUR A. SÁ

Departamento de Geologia, Universidade de Trás-os-Montes e Alto Douro, Vila Real, Portugal Centro de Geociências, Universidaded de Coimbra-Pólo II, Coimbra, Portugal

asa@utad.pt

DIEGO C. GARCÍA-BELLIDO

School of Biological Sciences, University of Adelaide, Australia

Diego.Garcia-Bellido@adelaide.edu.au

CÉSAR A. CHACALTANA

INGEMMET, Av. Canadá 1470, Lima, Peru

cchacaltana@ingemmet.gob.pe

\begin{abstract}
The cases of Joan Corbacho from Spain, and Klaus Hönninger and Carlos A. Vildoso from Peru, considered by some as prestigious paleontologists in their countries, are discussed here. The first one is a fossil collector and trader that, without a minimal scientific knowledge, published ca. 20 papers with proposals for a dozen new trilobite taxa coming from different Paleozoic formations in the Moroccan Anti-Atlas. Descriptions of new taxa seem formally valid but are rather inadequate, often based on poorly preserved material of dubious geological provenance, and mostly published as papers without peer review in a local journal, managed by a private museum connected to the Seminary of Barcelona. Besides this, part of the published and figured trilobite specimens were later offered for sale in the internet, sometimes accompanied with a 'certificate of authenticity' signed by the Museum director. Mr. Corbacho is acting also in Spain as a judicial expert in paleontology while he is not more than an amateur fossil collector. In Peru, the two cited pseudo-paleontologists lead their official-looking businesses, the MeyerHönninger Palaeontological Museum' and the 'Peruvian Institute of Paleovertebrate Studies', respectively, under names of institutional appearance. The 'scientific research' activities of Mr. Hönninger have been basically deactivated by authorities of the Ministry of Culture, and following a public complaint for fraud in the First International Symposium of Palaeontology of Peru held in 2014 in Lima. However, the dealings of the Mr. Vildoso, who has long claimed to have a title on Paleontology from the University of La Plata (Argentina), which he has never been able to show, has experienced a considerable increase, with paleontological heritage contracts with mining companies and the organization of the Dakar Rally. The prominence of the position he has attained is such that he was offered the presidency of the Organizing Committee of the IX Latin American Congress of Palaeontology held in 2016 in Lima, which has ended in an organization disaster and a money scandal.
\end{abstract}

\section{INTRODUCTION}

s occurred with the Gupta affair of the Himalayan 'misplaced' or 'recycled' fossils (Talent, 1989; Ruffel et al., 2012; Shah, 2013), or more recently with the Middle
East fossils of the Imam case (Aguirre, 2004; Granier et al., 2009), an increase of paleontological data from relatively remote or unexplored places of the world has attracted the incursion of opportunists into the research field. Here we present the case of various unethical practices 
detected in paleontological studies on the Ordovician of Morocco, as well as others affecting more general aspects of Peruvian paleontology. The African case involves ten years of palaeontological misconduct by a Spanish citizen, and is presented here for the first time. The two other cases of unethical procedure by Peruvian citizens have been partially discussed in a previous paper in Spanish (Gutiérrez-Marco et al., 2016), which is mostly translated and updated here with new information. The questionable activities of these three individuals were already known in circles of specialists, but the purpose of this note is to make these practices known outside their local areas, as well to the media and national administrations, so that no one can claim in the future the ignorance of these problems.

\section{THE 'CORBACHO AFFAIR'}

This case affecting the North-African paleontology began nine years ago, when Joan Corbacho, an amateur fossil collector settled in Sabadell (province of Barcelona, NW Spain) started to publish papers on Ordovician trilobites of Morocco without a minimal scientific knowledge. At the beginning Mr Corbacho coauthored with embriologist Dr. J.A. Vela (University of Barcelona), an amateur trilobite collector who is connected to the Geological Museum of the Seminary of Barcelona, later going alone or in collaboration with other people, most of them nonspecialists as well.

The geological museum of Barcelona deserves attention because it has a great responsibility in the origin and development of this affair. This is a non-governmental institution that was established in 1874 as the Natural History Cabinet of the catholic seminary (Vilella, 1999; Taylor et al., 2012), and whose collection management is in the hands of a large group of fossil amateurs and volunteers. From 1987, the museum published regularly the journal Batalleria, as well as the non-periodic series Musei Geologici Seminarii Barcinonensis (Series Palaeontologica), which started in 2006. The problem is that both journals published papers with inadequate or totally lacking peer review, especially when relating to 'discoveries' and contributions submitted by the Museum's main collabora- tors. This lack of scientific control is in the origin that $\mathrm{Mr}$. Corbacho, publishing preferentially in these two journals (see list of references), has flooded the literature on North African trilobites with putative new taxa, in their majority very poorly described and lacking precise geological context. The impact of this scientific "noise", materialized in almost twenty papers in ten years (2007-2017), varies according to the opinion of different specialists, but its repercussions cannot be fully envisaged as yet. Two views are being imposed among the professional scientists: those who prefer to ignore the new taxa proposed by $\mathrm{Mr}$. Corbacho and co-authors, and those who provisionally could accept some of these problematic names, in the hope of a future in-depth review of their diagnosis, synonymies and precise stratigraphic circumstances that will surely be a difficult and time-consuming job.

As an example of the first view, Martin et al. (2016) reported a general list of the Lower Ordovician trilobites identified from the Fezouata Shale, with no reference of the new taxa described by Mr. Corbacho from the same formation (Vela and Corbacho, 2007; Corbacho, 2008, 2014b; Corbacho and Vela, 2010, 2013; Corbacho and López-Soriano, 2012), with the single exception of Anacheirurus adserai (Vela and Corbacho, 2007). In senior synonymy with the latter there are probably up to six other Moroccan species described for the same area by Vela (2007), Vela and Corbacho (2007) and Corbacho (2008), partially reviewed by Vela and Corbacho (2011). Most of the figured specimens from these 'new species' certainly represent preservational or mechanical variants either taphonomic or crudely retouched in - of a single form of the genus Anacheirurus, which is a junior synonym of Lehua (Martin et al., 2016). As an example of the second option Gutiérrez-Marco et al. (2017) have used the name Megistaspis (Ekeraspis) hammondi (Corbacho and Vela, 2010), but stating that the original description of the species needs revision, because the diagnostic characters are barely recognizable on the holotype, and the purported differences with the subspecies $M$. (E.) hammondi forteyi could be due to preparation by fossil dealers'. On the other hand, the same late Tremadocian trilobite was cited as $M$. 
(E.) cf. filacovi by Martin et al. (2016), in the hope of a more complete study with better preserved material. A recurrent problem in the papers by Mr. Corbacho is that most of the original type material of his new species were inadequately prepared, or reconstructed by lo-
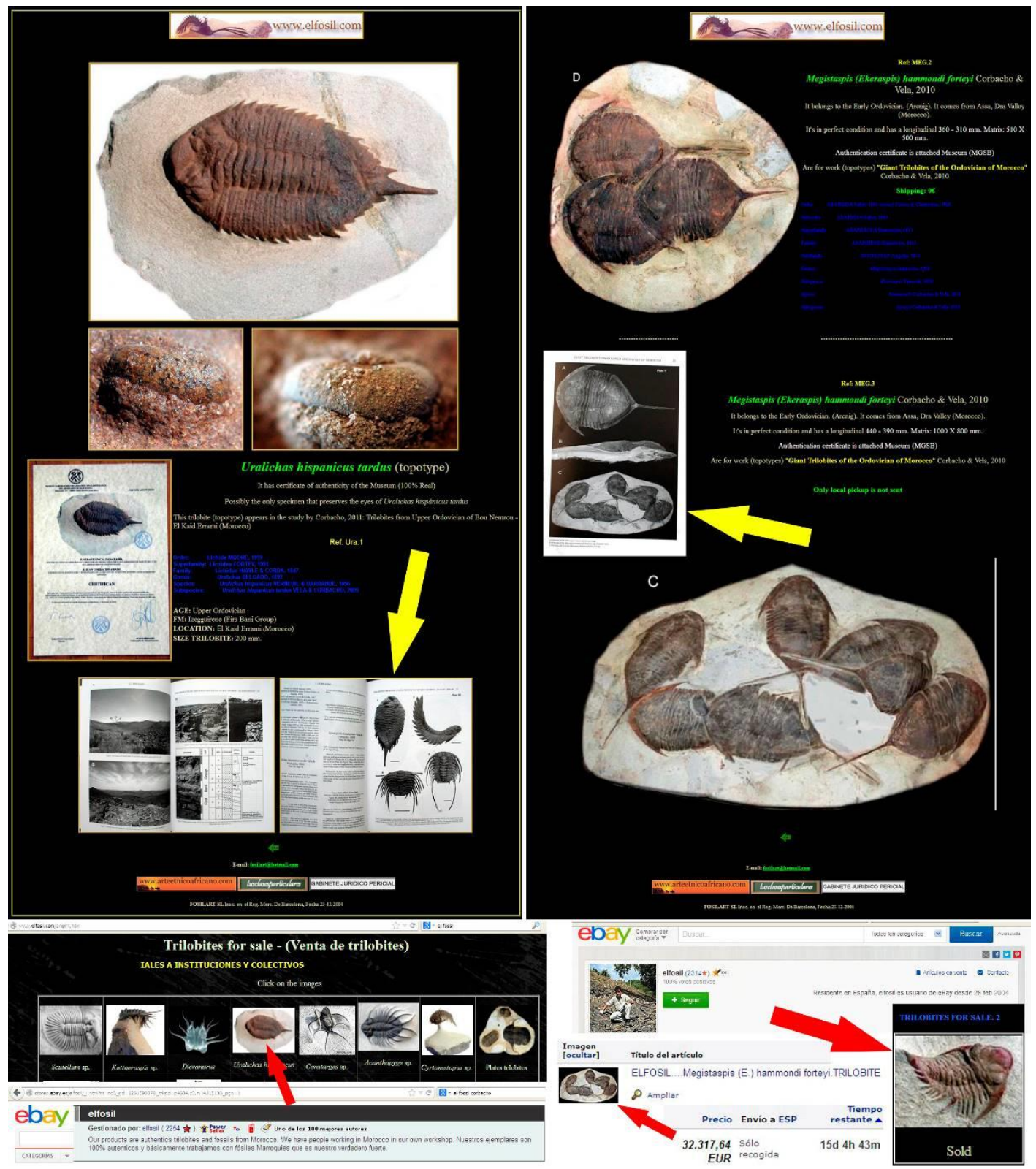

Figure 1: Composition of past screen captures showing Mr. Corbacho' Moroccan trilobites on sale in Internet. On the left-half, a topotype specimen of Uralichas hispanicus tardus figured in Corbacho (2011, pl. 3, fig. 1), and offered with a 'certificate of authenticity' signed by the Geological Museum of the Seminary of Barcelona. Despite the specimen being described as $100 \%$ real, it shows clear cosmetic reconstructions in cephalon, thorax and pygidium. To the right is a cluster of paratype specimens of Megistaspis (Ekeraspis) hammondi, figured by Corbacho and Vela (2010, pl. 5C) and also offered by eBay (bottom center) for a total of 32,317.64 Euros. Bottom left is an image of the holotype specimen of Parvilichas marochii, figured by Corbacho and Vela (2013, pl. 1, fig. 7) and found cited as 'sold'. Big upper arrows indicate plates and placement of specimens in the corresponding publications, lower ones refer to the same in the web list of sales. According to their records, the name 'elfosil' of Mr. Corbacho is used on eBay since February 28, 2004. 
cal dealers, because a great majority of his figured specimens were certainly acquired from Moroccan workers and fossil shops. Evidences of crude cosmetic improvements are often visible in many of the trilobites illustrated in his papers, as well as probable reconstructions of specimens put together from different individuals, a rather common practice in some local fossil workshops. This procedure is strange for a person who acts as a 'Legal expert in paleontology and gemology' and is 'responsible for the Fossil Authentication and trilobites' in the Geological Museum of the Seminary of Barcelona. Lacking any tertiary education in paleontology, Mr. Corbacho has obtained three titles from the Catalonian School of Criminology related to the 'Gemology and Metales preciosos' (=Gemology and Precious Metals), 'Peritajes y Tasación Judicial' (=Official Appraising) and a diploma in 'Falsificaciones y Tasaciones Paleontológicas' (=Paleontological Falsification and Appraisals). These were all received from a private center, collaborating with the also private European University Miguel de Cervantes of Valladolid, which offers access 'without academic requisites'. Mr. Corbacho is president of his own 'Associaciò de Perits i Taxadors de Catalunya' (five members). About fossil fakes and their recognition and legal expertise in paleontology he has written several papers with very elemental and obvious examples (Corbacho, 2009, 2015; Corbacho and Martínez, 2014, 2015; Corbacho and Sendino, 2015; Corbacho et al., 2007, 2011, 2015) and some made-up statistics (Corbacho et al., 2015, fig. 1). Despite this presumable experience and expertise and, as mentioned above, Mr. Corbacho established new species of trilobites based on material coarsely reconstructed or highly retouched by Moroccan dealers. This is the case, for instance, of Asaphellus cuervoae (Corbacho and LópezSoriano, 2012), a trilobite with exceptionally long and transverse genal spines, obviously generated as an 'improvement' with epoxy paste, probably based on poorly preserved specimens of A saphellus stubbsi (Fortey, 2009), a trilobite characterized by long moustache-like genal spines. The fact that the type material of A. cuervoae comprises retouched individuals with 6 and 7 thoracic segments, instead of 8 as occurs in all other asaphids, also points to paleontological falsification. But there's more: regarding the same species and material -all of commercial origin, Corbacho and Calzada (2014) speculate with the existence of a possible sexual dimorphism defined by the size and their occurrence in pairs, where they interpret that these couples could have fossilized when mating, after a sudden death by 'gases of volcanic origin'. This is the scientific level of papers published in Batalleria, that some often listed in the acknowledgements people having explicitly shown their disagreement with the content of certain manuscripts, and that latter see their name acknowledged in the publication (com. pers. Dr. J. Esteve, Dr. S. Zamora and Dr. I. Rábano).

With regard to the paleontological descriptions of new trilobite species, all of them are very simplistic and often bold, full of measurements taken from reconstructed material but outside common taxonomic practice. He has often chosen the worst specimen (least complete or worst preserved) as holotype, leaving the paratypes for private collections. Occasionally two holotypes have been selected for the same species (as for Symphysops stevaninae; LópezSoriano and Corbacho, 2012), and sometimes the holotype lacks the diagnostic characters (like the paratype with eyes and-abraded-pygidium, as opposed to the holotype cranidium of Degamella sendinoae; Corbacho, 2011). Once there is the added value of having been illustrated in a publication, Mr. Corbacho has offered some paratypes for sale on eBay or through his company's web site (Fig. 1), and even the holotype appeared as "sold". After these practices were denounced by the authors in two international meetings (October 2015 and August 2016), Mr. Corbacho took off the webpage section on 'trilobites for sale', from which we have compiled the images in Fig. 1. Mr. Corbacho, however, keeps publishing papers mainly regarding Ordovician trilobites, not only dealing with those of the Lower Ordovician Fezouata Shale (Corbacho and LópezSoriano, 2016; Corbacho et al., 2017), the formation which preserves the Fezouata Biota (Lefebvre et al., 2016), but also the more unknown Upper Ordovician Tafilalt Biota (Vela and Corbacho, 2009; Corbacho, 2011; LópezSoriano and Corbacho, 2012; Corbacho and 
Kier, 2011; Corbacho and López-Soriano, 2013c; Corbacho et al., 2014). Through his 'Fosilart' company he has announced two more papers and a book on Ordovician Moroccan trilobites, edited by the Geological Museum of the Seminary of Barcelona. Besides this geological period, Mr. Corbacho has expanded - occasionally sending material to professional paleontologists - to the study of the Cambrian trilobites of Morocco (Geyer and Corbacho, 2015) as well as Devonian trilobites from the Anti-Atlas (Corbacho and López-Soriano, 2013a, 2013b; Corbacho, 2014a, 2014c; Bignon et al., 2014). Finally, Mr. Corbacho has sent some non-trilobite fossils to a Czech specialist producing two joint notes (Valent et al., 2013; Valent and Corbacho, 2015), and recently has written general papers (Corbacho et al., 2016; Corbacho and Hammond, 2017). Most of the coauthors of Mr. Corbacho's papers are also amateur paleontologists (J.A. Vela, F.J. López-Soriano, C. Kier), fossil collectors (K. Hammond, D. Martínez Bautista, J.A. Cuevas, E. Moreno), non-trilobite specialists (A. Ait Addi, S. Calzada, C. Sendino) or even fossil dealers (M. Tahiri).

\section{THE 'HÖN NINGER AFFAIR'}

In 2009, the Peruvian media reported that Klaus Hönninger Mitrani, computer engineer working as an amateur paleontologist, had established in Laredo (Trujillo) the 'first Peruvian paleontological museum' according to some newspapers, or 'the first Latin American paleontological museum' according to other sources. This is the Museo Paleontológico MeyerHönninger, a private company registered as an association NCP (= 'of unclassified activity') on August 17, 2009 by Mr. Hönninger, a Chiclayan born of German and Peruvian descent. This enthusiast of paleontology had assembled a collection of genuine fossils and dinosaur replicas during his stay in Germany, and intended to disseminate this aspect of science in his country, raising public awareness about the importance of knowing and protecting the rich Peruvian paleontological heritage. His exhibition of fossils toured various sites (Trujillo, Chiclayo, plus the districts of Surco and Villa El Salvador, in Lima). At the same time, some journalists began to regard him as a true pro- fessional paleontologist of great national and international prestige. This view was fuelled by Mr. Hönninger himself through Wikipedia and the social networks, where he was even treated as a 'public figure' in Facebook.

The media history of Mr. Hönninger includes alleged discoveries of important Peruvian fossils, never backed by scientific publications but aired to the media with obvious ignorance of the previous paleontological literature, such as 'the first skeleton of Megalodon found in the world' (2006), a complete Smilodon skull (2009), a Neogene braincase mold of Kentriodon (2010), seven new Albian species from the Amazonia (2011), Miocene amber with insects, arachnids, microfossils and rodent hairs (2011), etc. some of them even broadcasted by the BBC in April 2011. He even claimed the authorship of what he called 'Hönninger Hypothesis', which suggests that the mass extinction of the $\mathrm{K} / \mathrm{Pg}$ boundary would have begun, due to climatic causes, five million years before the fall of the Yucatan asteroid, leading to the dwarfing of certain foraminifera that he has never specified. The background of Mr. Hönninger' paleontological knowledge was apparently based on two fake degrees in the speciality: the first one obtained at the 'Praehistorica Institut' of Hanau (Germany), which is a private fossil preparation laboratory, partly with commercial purposes, directed by Mr. Ingo Meyer. The second putative title comes from the US 'Wyoming Dinosaur Center', another private company that maintains a payment program (Dinosaur Academy) to teach how to dig dinosaurs to high school students. In its deleted page in Wikipedia, Mr. Hönninger was proclaimed an 'honorary member' of both institutions.

In his most popular years in the media, Mr. Hönninger starred in an alleged 'encounter in the third phase' in the Ocucaje desert, with long-headed extraterrestrials that reminded him of the skulls deformed by the Paracas civilization. It was at that stage when he was interviewed by the Spanish TV program 'Fourth Millennium', deployed to Peru to that effect (Fig. 2).

Initially invited by the Peruvian cultural authorities to intervene in the regulation of the nation's paleontological resources (September 2012), Mr. Hönninger soon became envious of 
the members of the current Ministry of Culture,

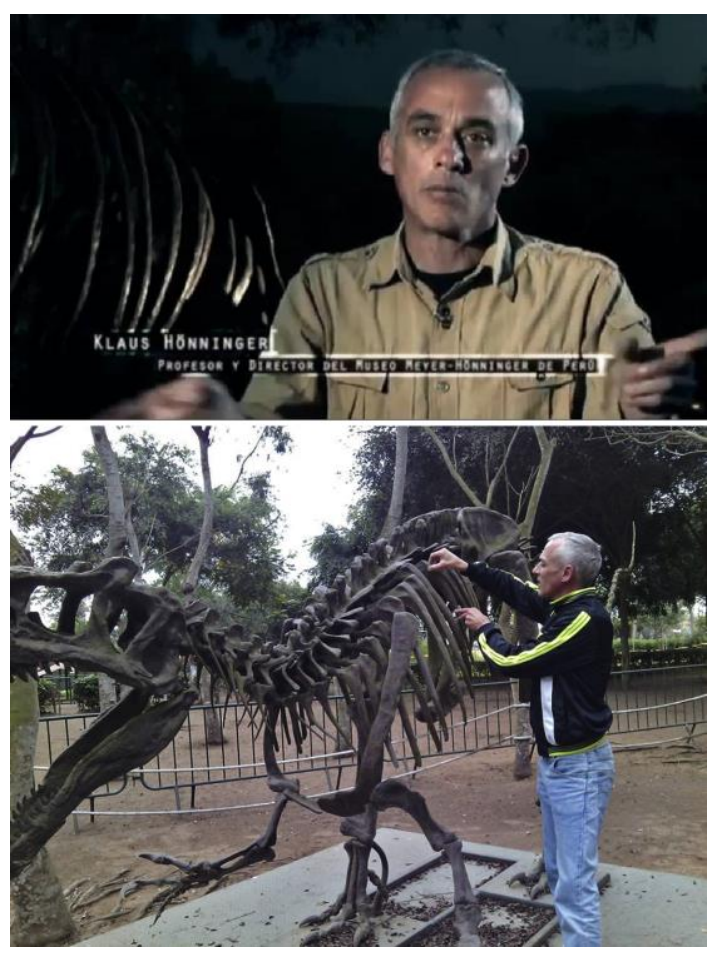

Figure 2: Above: Screen capture of Mr. Klaus Hönninger, participating in the television program 'Cuarto Milenio' ('Fourth Millenium', Channel 'Cuatro', Spain, 2012). The subscript reads 'professor and director of the Museo Meyer-Hönninger of Peru'. Below: $M r$. Klaus Hönninger with a dinosaur replica in his exhibition in Lima (Peru), from Facebook (open access).

for maintaining strong personal opposition to the traced itinerary of the 'Rally Dakar' to cross the deserts of Ica and Ocucaje in 2013 and 2015. This race caused in 2012 severe damage in the extensive deposits with fossil cetaceans and other marine vertebrates, not only by the vehicles, but also their participant's camps and spectators. This opposition led him to report to the media that he received death threats against him (using blood-stained Colombian bills), and that a group of 50 Right Livelihood Award winners (described by some as the "Alternative Nobel Prize") wrote to the Peruvian government requesting personal protection for Mr. Hönninger (May 2013).

Following his disagreement with the authorities of the Ministry of Culture, who since 2013 began to monitor the legality of his paleonto- logical prospects, Mr. Hönninger was also questioned at an invited conference, given in September 2013, during the First International Symposium on Peruvian Paleontology held in Lima, where his multiple opportunistic activities and professional intrusions came to light (Gutiérrez-Marco, 2014). It was then when he began to decline in his work as a pseudopaleontologist, shortly after Mr. Hönninger signed agreements with the private university Ricardo Palma (Lima), and also with the municipality of Lima, to build the so-called 'Dinopark' in the Huáscar Zonal Park of Villa El Salvador (a district south of Lima).

This project was publicized as the 'first Peruvian museum of Paleontology', having a budget of about US\$ 1.3 Million. But after an informative exhibition was held for several years at the site of the future museum, with an open-air display of replicas of skeletons and dinosaur models, the project was 'frozen' and was finally dismissed at the beginning of 2015, being replaced by the construction of sport installations in the same area. However, Dinopark has managed to become a future 'Paleontological Theme Park and Museum of Humanity' which, also under the direction of Mr. Hönninger, is expected to be located in the city of Tacna, hopefully with exclusively informative and disconnected objectives of research or paleontological rescue.

Today, Mr. Klaus Hönninger no longer publicly boasts of his past status as a paleontologist but, after his frustrated passage through politics (in 2014 opted for the presidency of the Regional Government of Lambayeque), now adays he splits his time between the direction of the 'Meyer-Hönninger Museum' (virtual in the present moment?) and the positions of 'Principal Investigator' and 'Director of International Affairs' of the Instituto de Investigaciones y Estudios Socio-Territoriales (Institute of Research and Socio-Territorial Studies-IIEST). The latter is a new private company (NCP-Association, Lima 2015), whose name denotes institutional appearance, and where Hönninger's curriculum is almost unrelated to Paleontology, although it maintains several dubious references regarding its past and present non-paleontological activities. 

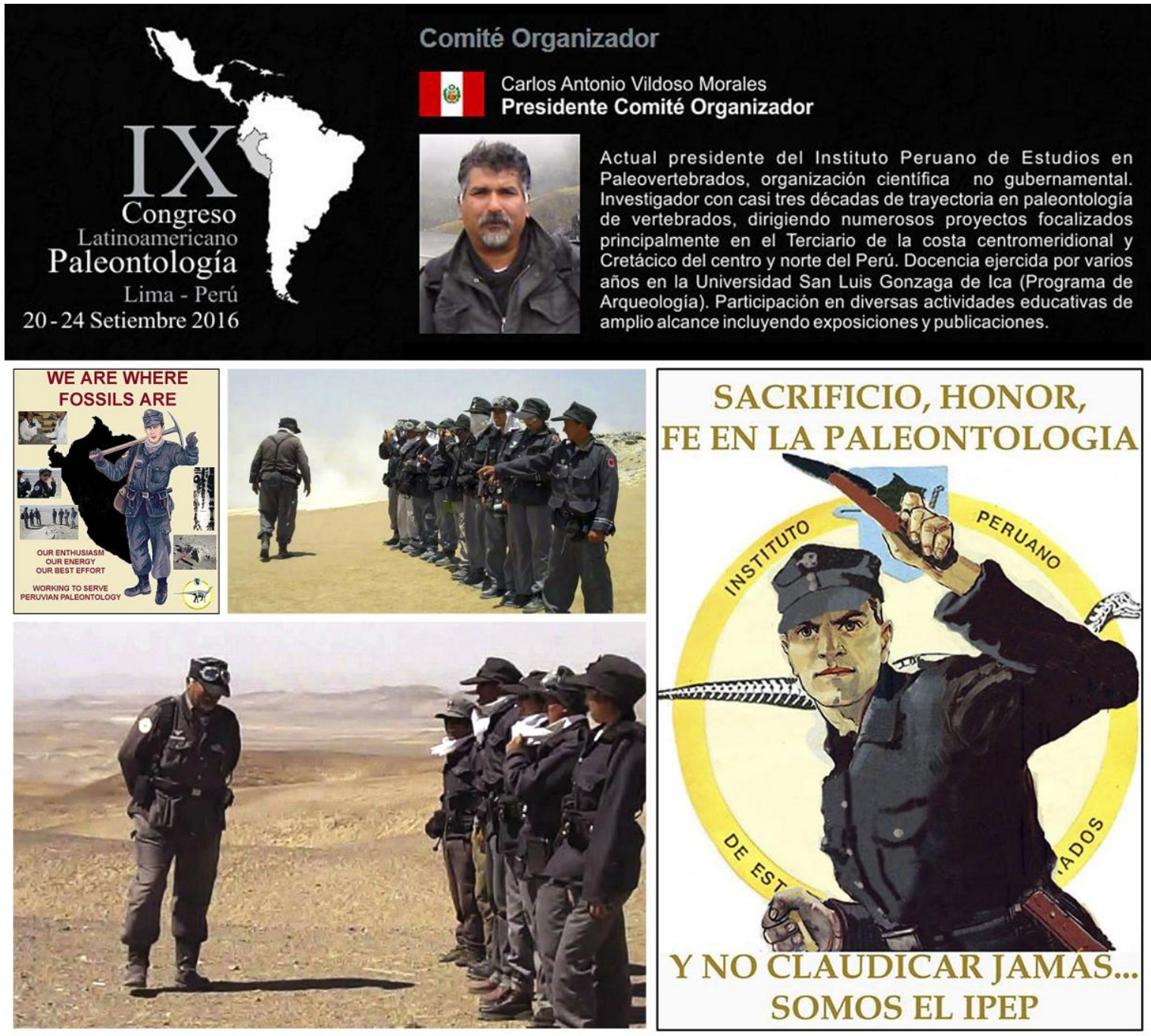

Figure 3: A bove: screen captures and composition of images taken from the website of the IX Latin American Congress of Paleontology, showing the president of the organizing committee, Mr. Carlos A. Vildoso, with his curriculum. Below: paramilitary esthetics and propaganda among the participants of the company 'Instituto Peruano de Estudios en Paleovertebrados'. Bottom left: the president, Mr. Carlos A. Vildoso. Images from Facebook (open access).

\section{THE 'VILDOSO AFFAIR'}

This case overlaps in time with the previous one but even more convoluted, given that its protagonist, the publicist Carlos Antonio Vildoso Morales, claimed at the beginning to have graduated as a paleontologist in 1990 from the University of La Plata (Argentina). A statement denied by his academic record, which proves that he only attended seven subjects of the degree in Biology, of which he passed three, losing his status as a regular student in 1991. After being involved in various controversies for breach of contracts in the Museum of La Plata (Argentina) and in the National Museum of Peru, in 1995 he founded the Instituto Peruano de Estudios en Paleovertebrados- IPEP (= Peruvian Institute of Studies in Paleovertebrates). This is a private commercial company registered as an Association of Unclassified Activity (NCP), through which Mr. Vildoso gets contracts of projects with mining companies for rescue and protection of paleontological elements, as well as with the French company or- 
ganizing the Rally Dakar 2014, in order to proceed to the demarcation of 'in situ' vertebrate fossil skeletons that could be affected by the layout of this famous race (Fig. 3). Other sources of funding for the institute include the organization of itinerant paleontological exhibitions, the sale of educational materials and the publication of a magazine (Vildoso Morales, 2012). The journal Contribuciones Paleontológicas del Instituto Peruano de Estudios en Paleovertebrados, the 'official publication' of the IPEP, is not traceable by bibliographic means. In the cover image of its first number (vol. 1 for the year 2013, according to the webpage of the IPEP) it indicates the ISSN 225-2797 (sic). But in the ISSN global database the journal appears as initiated in 2010 under the ISBN number 22252797, lacking a deposit in the National Library of Peru as should be expected. Another anomaly is that this journal is not included in the WorldCat database, which raises doubts over its existence.

Being an active person in the media of his country and in social networks, Mr. Vildoso regularly works as a research paleontologist, despite the absence of recognized paleontological training, which can be qualified as a kind of unqualified practice. The results of his alleged investigations, in some cases totally invented paleontological discoveries, were 'published' by the journal of the IPEP and in some conference abstracts that have assumed, in good faith, the integrity of its authors. There is no record of international research publications with $\mathrm{Mr}$. Vildoso as author or co-author, nor does he appear with any in the National Directory of Science and Technology Researchers of Peru.

From the journalistic information it is deduced that Mr. Vildoso possess a valuable collection of Peruvian fossils, estimated by himself at about 50,000 specimens, that he apparently keeps in his private residence, according to a personal interview published by the Peruvian journal La República. Only in this early article (January 14, 2013), he qualified himself as a 'lover of paleontology -but not a paleontologist'. However, in March 2016, and acting as President of the IX Latin American Congress of Paleontology, his curriculum vitae changed to 'a researcher with almost three decades of experience in vertebrate paleontology', teaching for several years in the program of Archeology of the University San Luis Gonzaga of Ica (Fig. 3).

The position of Mr. Carlos Vildoso as Chairman of the Organizing Committee of this congress deserves more attention. This meeting was held in the main building of the Ministry of Culture in Lima between September 20-24, 2016, with the IPEP in charge of treasury through a personal bank account of its director. The number of accounting irregularities were such, that Mr. José Apolín, representative of the Ministry of Culture and acting as chairman of the Ethics and Regulations of the Peruvian Congress defined the handling by Mr. Vildoso a 'planned embezzlement', which would have affected that ministry and scientists from 14 countries. The economic balance presented by the president at the end of the congress was very unsatisfactory also in words of Dr. JeanNoël Martínez, who acted as chairman of the Scientific Committee of a congress that had a minuscule local participation (6 posters from Peru).

\section{FINAL REMARKS}

Examples of recent methodological and ethical misconduct in paleontological science affecting Morocco and Peru are presented here. Most of the former remain unknown outside the limited circles of specialists but could introduce confusion in the future. There is an important risk that these poor descriptions and contaminated Moroccan data may be utilized for regional geology or in global paleontological databases, affecting the conclusions reached in paleogeographical, stratigraphical or other geological analyses. The latter problem is the social projection so far reached by the false Peruvian paleontologists deteriorating the image of true professional paleontologists of this Andean country.

The activities of the Spanish fossil collector and trader Mr. Joan Corbacho led to the publication of several dozen new trilobite taxa coming from Morocco, in absence of true scientific taxonomical study and precise geological data about the different type localities. The type material of the new species selected to be housed in institutional repositories is barely repre- 
sentative, while much better specimens remain in private hands. The best-preserved paratypes have been in part offered for sale in internet (even the figured specimens) with a 'certificate of authenticity' signed by the director of the Geological Museum of the Seminary of Barcelona, the same institution that edited the journals where the papers describing the new Moroccan species were published without any scientific control or peer-review process by specialists. Mr. Corbacho considers himself as a true 'expert in paleontology' in the museum and demonstrates his condition by publicizing him as a member of the Spanish Society of Paleontology (which is open to all types of public). Despite his private titles in paleontological falsifications and appraisals, many of the new trilobite species proposed by Mr. Corbacho are based on specimens retouched by Moroccan dealers. This fact, added to the lack of precise stratigraphic information and a good taxonomic study, introduces more problems than benefits to North African paleontology.

The false history as paleontologist of Mr. Klaus Hönninger was deleted from Wikipedia in early 2014, after being classified as 'promotional' by several editors, and because it exclusively contained references to non-scientific journalistic articles. Apart from that, he is the author of a small book entitled Buscando al gigante ('Looking for the giant', San Marcos Ed., Lima 2014), referring to the campaigns to find the 'Megalodón' (= the giant shark Otodus (Megaselachus) megalodon) in the Ica desert. The contents that Mr. Hönninger now disseminates in social networks are mostly impregnated with philosophical, environmental and archeological connotations, or showing its ongoing personal opposition, for example, to "trash TV" and the return of the Rally Dakar to Peru, but with only few paleontological references. However, by the beginning of November 2016 Mr. Hönninger erroneously appeared in the list of the 'Five Peruvian Scientists admired by the world', an initiative from Cienciactiva (= 'Active Science'), which depends from the Consejo Nacional de Ciencia, Tecnología e Innovación Tecnológica (CONCYTET, an equivalent to the USA National Science Foundation - NSF). Upon this error being realized, the people responsible replaced Mr. Hönninger's name by that of a Peruvian scientist of unquestionable international reputation.

However, Mr. Carlos Vildoso was recently reported to the Minister of Culture of Peru by the Society of Vertebrate Paleontology, requesting an investigation into the organization and financing of the IX Latin American Congress of Paleontology. This international society accused him of serious irregularities experienced by members of the paleontological scientific community who participated in the meeting, such as keynote speakers not issued with airline tickets, scheduled field trips not celebrated and with unreturned fees to participants that had paid in advance, besides a general disorganization and lack of scientific coordination and attention to participants. A similar statement has been put out by the Geological Society of Peru as well as by Dr. Rodolfo SalasGismondi, director of the Department of Vertebrate Paleontology of the Natural History $\mathrm{Mu}$ seum (National University of San Marcos, Li$\mathrm{ma}$ ). The latter has published on the internet numerous accredited documents on these accusations and others on the lack of ethics of Mr. Vildoso. This was replied by Mr. Vildoso asking for a public retraction of these statements in February 10, 2017, which to this date has not taken place.

Paradoxically, researchers from the Natural History Museum of Lima are almost the only ones that produce relevant paleontological results measured in terms of the impact factors established by international databases (WoK, Scopus...), followed by few other universities and by paleontologists of INGEMMET (the Peruvian Geological Survey). With the exception of those from the University of Piura and two other Limean private universities, most of the renowned Peruvian paleontologists were not invited in due time to join the candidacy of Lima as the site of the IX Latin American Congress of Paleontology, finally presided by C.A. Vildoso. According to written statements by Dr. Salas-Gismondi, Mr. Vildoso is suspected to be involved in the numerous anonymous $\mathrm{Fa}$ cebook pages full of racist, sexist and homophobic assertions, intended to insult and disqualify the members of the Department of Vertebrate Paleontology of the Natural History Museum. 


\section{ACKNOWLEDGMENTS}

We are grateful to the various American and European colleagues who have provided us with a very valuable documentary safeguard, with which to support all the statements made. Thank you to Dr. Abdelouahed Lagnaoui (University of El Jadida, Morocco) and an anonymous referee for their contributions improving the manuscript.

\section{REFERENCES}

Aguirre J. (2004). Plagiarism in Palaeontology. A new threat within the scientific community, Rev. Española Micropaleont., 36, 349-352.

Bignon A., Corbacho J. and López-Soriano F.J. (2014). A revision of the first Asteropyginae (Trilobita; Devonian), Geobios, 47, 281-289.

Corbacho J. (2008). Tres nuevas especies de Lehua del Ordovícico inferior del Valle de Draa (Marruecos), Scripta Mus. Geol. Seminar. Barcinonen sis [Ser. palaeontol.], 5, 3-13.

Corbacho J. (2009). Falsificación de fósiles del N. de África (no trilobites). Batalleria, 14, 53-56.

Corbacho J. (2011). Trilobites from the Upper Ordovician of Bou Nemrou - El Kaid Errami (Morocco). Batalleria, 16, 16-36.

Corbacho J. (2014a). Lanceaspis hammondi n. gen., n. sp. - a questionable early Asteopyginae (Trilobita) from the Pragian of the Morocco. Batalleria, 20, 3-10.

Corbacho J. (2014b). Kierarges morrisoni: Un nuevo género de Isotelinae (Trilobita) del Floiense de Portugal y Marruecos. Batalleria, 20, 21-26.

Corbacho J. (2014c). Struveaspis bignoni: Nueva especie de Phacopidae (Trilobita) de Marruecos; Devónico Medio (Eifeliense), Scripta Mus. Geol. Seminar. Barcinonensis [Ser. palaeontol.], 16, 3-12.

Corbacho J. (2015). Peritajes y tasaciones en paleontología. Trabajo de Título Propio Escuela Internacional de Criminología, Universidad Europea Miguel de Cervantes, Valladolid, 7 pp., doi 10.13140/ RG.2.1.1872.8489.

Corbacho J. and Calzada S. (2014). Posible dimorfismo sexual en Trilobites del Ordovícico inferior. Batalleria, 21, 22-26.

Corbacho J. and Hammond K. (2017). Técnicas de limpieza y recuperación de trilobites marroquíes. Batalleria, 24, 9-16.
Corbacho J. and Kier C. (2011). Trilobites of a new outcrop of Upper Ordovician in Jbel Tijarfaïouine, El Kaid Errami (Morocco), with first mention of genus Corrugatagnostus, Scripta Mus. Geol. Seminar. Barcinonensis [Ser. palaeontol.], 10, 3-14.

Corbacho J. and López-Soriano F.J. (2012). A new asaphid trilobite from the Lower Ordovician (Arenig) of Morocco. Batalleria, 17, 3-12.

Corbacho J. and López Soriano F.J. (2013a). Diversidad y distribución de Acanthopyge (Belenopyge), (Lichidae) en Marruecos; Devónico inferior y medio. Batalleria, 18, 3-14.

Corbacho J. and López-Soriano F.J. (2013b). Two new species of Trochurinae trilobites from the Middle Devonian (Eifelian) of Southern Morocco. Batalleria, 18, 15-24.

Corbacho J. and López-Soriano F.J. (2013c). Chattiaspis? budili: a new Dalmanitidae species from Morocco; Upper Ordovician (Lower Katian). Batalleria, 19, 6-12.

Corbacho J. and López-Soriano F.J. (2016). Platypeltoides hammondi (Trilobita, Nileidae): A new species from the Upper Tremadoc of the Dra Valley, Morocco. Batalleria, 23, 11-19.

Corbacho J. and Martínez D. (2014). Perito ju dicial en paleontología: Una nueva visión. Comunicats Inst. Cat. Miner. Gemmol. Paleontol., 3839, 71-72.

Corbacho J. and Martínez Bautista D. (2015). Sobre peritajes y tasaciones en paleontología. Comunicats Inst. Cat. Miner. Gemmol. Paleontol., 5, 40-41.

Corbacho J. and Sendino C. (2015). Fossil fakes and their recognition. Deposits Mag., 30, 3540.

Corbacho J. and Vela J.A. (2010). Giant Trilobites from Lower Ordovician of Morocco. Batalleria, 15, 3-32.

Corbacho J. and Vela J.A. (2011). Revisión de las especies de Lehua de la región de Zagora (Marruecos). Batalleria, 16, 46-49.

Corbacho J. and Vela J.A. (2013). Parvilichas marochii: New genus and species of Lichidae from the Zagora region (Morocco); Early Ordovician (Floian). Scripta Mus. Geol. Seminar. Barcinonensis [Ser. palaeontol.], 14, 3-13.

Corbacho J., Corbacho I., Morrison S. and Valent M. (2015). Últimas técnicas detectadas en la falsificación de fósiles. Batalleria, 22, 22-27. 
Corbacho J., Hammond K., Moreno E. and Morrison S. (2016). Paleontología y Coleccionismo. Batalleria, 23, 43-46.

Corbacho J., López-Soriano F.J., Lemke U. and Hammond K. (2017). Platypeltoides carmenae: A new Nileidae (Trilobita) from the Lower Ordovician (Tremadocian) of Guelmim area; Western Anti-Atlas, Morocco. Batalleria, 25, 20-29.

Corbacho J., Morrison S. and Ait Addi A. (2014). Dionide carlottae: Una nueva especie de Dionididae (Trilobita) del Ordovícico superior de Marruecos. Batalleria, 21, 13-21.

Corbacho J., Sendino C. and Tahiri M. (2011). Palaeontological fakes- Batalleria, 16, 37-45.

Corbacho J., Vela J.A. and Cuevas J.A. (2007). Falsificación de trilobites del norte de África. Batalleria, 13, 29-36.

Fortey R.A. (2009). A new giant asaphid trilobite from the Lower Ordovician of Morocco. Mem. Assoc. Australas. Palaeontol., 37, 9-16.

Geyer G. and Corbacho J. (2015). The Burlingiidae (Trilobita): revised generic composition, stratigraphy, and the first species from the early Middle Cambrian of West Gondwana. GFF, 137, 212-225.

Granier B., Feist M., Hennessey E., Bucur I.I. and Senowbari-Daryan B. (2009). The Imam case. Additional investigation of a micropaleontological fraud. Carnets Géol., 2009/ 04, 1-14.

Gutiérrez-Marco J.C. (2014). La Paleontología peruana actual a través de las bases de datos internacionales: científicos, aficionados e intrusos oportunistas. In: I Simp. Int. Paleont. Perú, INGEMMET, Lima, 134.

Gutiérrez Marco J.C., Sá A.A. and García-Bellido D.C. (2016). Dos casos de intru sismo científico en la paleontología peruana. Geotemas, 16(2), 359-362.

Gutiérrez-Marco J.C., García-Bellido D.C., Rábano I. and Sá A.A. (2017). Digestive and appendicular soft-parts, with behavioural implications, in a large Ordovician trilobite from the Fezouata Lagerstätte, Morocco. Sci. Rep., 7, 39728, 7 pp. + Suppl. Figs. 1-3.

Lefebvre B., Lerosey-Aubril R., Servais T. and Van Roy P. (Eds.) (2016). The Fezou ata Biota: an exceptional window on the CambroOrdovician faunal transition. Palaeogeogr., Palaeoclimatol., Palaeoecol., 460, 178 pp.
López-Soriano F.J. and Corbacho J. (2012). A new species of Symphysops from the Upper Ordovician of Morocco. Batalleria, 17, 3-12.

Martin E.L.O., Vidal M., Vizcaïno D., Vaucher R., Sansjofre P., Lefebvre B. and Destombes J. (2016). Biostratigraphic and palaeoenvironmental controls on the trilobite associations from the Lower Ordovician Fezouata Shale of the central Anti-Atlas, Morocco. Palaeogeogr., Palaeoclimatol., Palaeoecol., 460, 142-154.

Ruffel A., Majury N. and Brooks W.E. (2012). Geological fakes and frauds, Earth-Sci. Rev., 111, 224-231.

Shah S.K. (2013). Himalayan Fossil Fraud - A view from the galleries. Palaeontol. Soc. India, Spec. Publ. 4, 140 pp.

Talent J.A. (1989). The case of the peripatethic fossils. Nature, 338 (6217), 613-615.

Taylor P.D., Sendino C. and Corbacho J. (2012). A hidden gem in the heart of Barcelona: the Geological Museum of the Seminary. Deposits Mag., 32, 46-48.

Valent M. and Corbacho J. (2015). Pauxillites thaddei a new Lower Ordovician hyolith from Morocco. Acta Mus. Nat. Pragae, Ser. B-Hist. Nat., 71(1-2), 51-54.

Valent M., Corbacho J. and Martínez D. (2013). Hyolith localities of Zagora region (Morocco), Upper Fezouata Formation (Lower Ordovician). Batalleria, 19, 20-23.

Vela J.A. (2007). Three new species of Lehua from Lower Ordovician of Dra Valley (Morocco), Scripta Mus. Geol. Seminar. Barcinonensis [Ser. palaeontol.], 4, 24-37.

Vela J.A. and Corbacho J. (2007). A new especies sic- of Lehua from Lower Ordovician of Dra Valley of Morocco- Batalleria, 13, 75-80.

Vela J.A. and Corbacho J. (2009). New trilobites from Upper Ordovician of El Kaid Errami, Morocco. Batalleria, 14, 99-106.

Vild oso Morales C.A. (2012). Paleontology in Peru: just beginning. Palaeontologia Electronica, 15, 2-3E, $7 \mathrm{pp}$.

Vilella J. (1999). 125 años del Museo Geológico del Seminario de Barcelona (1874-1999). Comunicats Inst. Cat. Miner. Gemmol. Paleontol. [5], 8-9, 27-28. 